\title{
Indigenous knowledge of terrace management in Paundi Khola watershed, Lamjung district, Nepal
}

\author{
Karun Pandit† and Mohan K Ballał \\ † Ministry of Forestsand Soil Conservation, Singh Durbar, PO Box 21645, Kathmandu, NEPAL \\ ‡ Department ofWatershed Management and Environmental Science, Instituteof Forestry, Tribhuvan University, \\ PO Box 43, Pokhara, NEPAL \\ *Towhom correspondenceshould beaddressed. E-mail:karunpandit@hotmail.com
}

\begin{abstract}
The study was carried out in the Paundi Khola watershed, Lamjung district, with the objective of evaluating the indigenous knowledge of terrace management. Various biophysical practices and land husbandry practices were recorded through field observation. A questionnaire survey and group discussions were also undertaken to acquire relevant information. It was found that terrace width and riser height correlated with slope angle negatively and positively, respectively. Outward-sloped terraces were common in the higher slope classes. Bund plantation was rarely observed in the irrigated fields. Paddy was the preferred crop wherever sufficient water was available. Paddy cultivation on unstable slopes without proper irrigation and drainage systems was the usual cause of slumping. Despite the failure of terraces or slopes in areas with deep-seated slides, farmers continued paddy cultivation by temporarily supporting and stabilizing the terraces until this was no longer feasible and major slope failure occurred. Gradual replacement of paddy by other more appropriate upland crops may sort out this problem to some extent.
\end{abstract}

Key words: Terraces, watershed management, slopefailure, bund plantation, slumping

Him J Sci 2(3): 33-36, 2004

Available online at: www.himjsci.com
Received: 16 May 2003

Accepted after revision: 8 Mar 2004
Copyright@ 2004 by Himalayan Association for the Advancement of Science (HimAAS)
In spiteof theagrarian natureof thecountryand thecommitment of His Majesty's Government (HMG) to supportagriculture, there is an increasing concern that agricultural production is declining in Nepal. The population growth is accelerated by low literacy rate. Both the amount of arableland per capita and productivity per unit area are declining (Mahat 1987). To overcome this problem, farmers are forced to extend cultivation to marginal areas, intensify farming practices, and increasingly seek offfarm employment. Agricultural land expansion means deforestation, which leads to increased risk of natural hazards. Improper intensive agriculture practices may accelerate soil erosion. It has been estimated that asmuch as $1.63 \mathrm{~mm}$ of topsoil is washed away from the total land surface of Nepal every year (DSC 1992).

To cope with such disastrous situations, farmers have developed several techniquesfor maintaining and improvingcrop productivity through soil and water conservation. Someexamples of indigenous soil fertility management in the mid-hills of $\mathrm{Nepal}$ are terracing, slicing the walls of terrace risers, allowing flood water into fields, in-situ manuringand inclusion of variouslegumes in crop rotations (Pandey et al. 1995). Thesuccess of a development projectoften depends on local participation, which inturn depends on the familiarity of the agents with the indigenous knowledge. Integration of indigenous knowledge in the development or selection of technology recommendations demonstrates sensitivity to thelocal culture, which facilitatesthe dissemination of technology (Hafeez 1998, Warren 1991). Therefore, before implementing any programme, it is essential to identify existing indigenous knowledgeand to evaluateits effectiveness.

According to Pratap and Watson (1994), terrace improvement isoneof theoldestindigenousconservation practicesin the Hindu Kush Himalayan region. It is a package program that com- prises several activities, including construction and leveling of terraces, riser trimming, construction of drainage, contour strip and grass plantation, and pond construction. The present study was carried out to identify and evaluate the indigenous knowledge of terrace management in the Paundi Khola watershed (PKW), Lamjung district, western Nepal.

\section{Materials and methods}

Study area

Paundi Kholaisatributary of the Marsyangdi River. Itswatershed lies in Lamjung district, Western Development Region, between $28^{\circ} 05^{\prime} 00^{\prime \prime}$ and $28^{\circ} 12^{\prime} 30^{\prime \prime} \mathrm{N}$ and $84^{\circ} 17^{\prime} 30^{\prime \prime}$ and $84^{\circ} 27^{\prime} 30^{\prime \prime}$ E. It coversan area of 5,877 ha and includes 12 village development committees: Sundarbazar, Tarku, Parebadanda, Chandreswar, Duradanda, Gaunsahar, Purankot, Kunchha, Dhuseni, Jita, Udipur and Sindure.

Thetotal population of PKW in 1995 was 8,862 , about $5 \%$ of the total population of the Lamjung district. Thetotal number of householdsin the area was 1,774 and the population density was 150.79 inhabitants per square kilometer in the year 1998 (DSCO 1998). The majority of the inhabitants of the watershed are Gurungs, followed by Brahmins, Chhetris and Tamangs. Members of occupational castes such as Damai, Kami, and Kumal, also inhabit the area. Almost $90 \%$ of the total population depends on agriculture, while $4.5 \%$ have permanentemployment outsidethe village. The rest of the population iseither engaged in small business, wage-labor, or teaching at local schools. The number of inhabitants per hectare of agricultural and forest land is 2.18and 4.88 , respectively.

Theelevation varies widely within the watershed from approximately 600 to $1,830 \mathrm{~m}$ asl. Land can be categorized according to slope into five different classes. PKW terrain falls within 
four of these slope classes, with slope class I being absent. The slopeclasses and their respective area in the PKW are presented in Table 1

About $69 \%$ of the watershed is under cultivation, of which level and sloping terraces constitute $34 \%$ and $35 \%$, respectively, of the entire watershed; the remaining $31 \%$ consists of forest and shrub lands (Figure1). Dueto thewidealtitudinal variation within the watershed, variations in forest composition are marked. The southern part of the watershed is characterized by temperate forest with major species such as Schima wallichii, Castanopsis indica and Alnus nepalensis, while the northern part is covered abundantly with pinealong with Rhododendron.

\section{Methodology}

Relevant biophysical and socio-economic information was collected using both primary and secondary sources. Primary data was collected through field observation, a questionnaire surveys and group discussion. Duringthefield observationscarried out in December 2000, pertinent biophysical parameters, includingterrace dimension, slope, and aspect, as well as land husbandry practices, such as cropping pattern, irrigation, and drainage infrastructure, were studied and recorded.

Themain patches of agricultural land in thewatershed were traced from the LRMP (1986) land utilization map. By overlaying topographical and land utilization maps, we separated agricultural land slope classes. Five sample units were selected from each of the slope classes, distributing them spatially over ridge, middle and base portions of the watershed including all types of terrain, such asirrigated and non-irrigated land.

A questionnaire survey was carried out to collect information not obtainablethrough field observation. A total of 62 households were included in the questionnaire survey. The questionnaire was designed to elicit information on slope maintenance practices, type of terrace preferred, bund plantation, irrigation
TABLE 1. PKW slope classes and their respective areas

\begin{tabular}{llll}
\hline Slope class & Slope \% & Area (ha) & \% of total area \\
\hline II & $3-15$ & 605 & 10.30 \\
\hline III & $15-30$ & 69 & 1.17 \\
\hline IV & $30-60$ & 3396 & 57.78 \\
\hline V & $>60$ & 1807 & 30.78 \\
\hline Total & & 5877 & 100.00 \\
\hline
\end{tabular}

(Source: DSCO 1998)

practices, crop preference, forest resource use, and indigenous knowledge regarding soil and water conservation. Separategroup discussions were carried out with local leaders and innovative farmers to assess needs, interests and preferences regarding agriculture and natural resources.

Relevant secondary data and information regarding the study area were collected from the District Soil Conservation Office, Lamjung.

\section{Results and discussion}

Relation between slope and terrace dimension

The local farmers constructed terraces with narrower width in thehigher slopeclassesthan in thelower slopeclasses $\left(R^{2}=-0.78\right)$ (Figure 2). They were well aware of the fact that increasing the width of the terraces on steep slopes entails more effort both in construction and maintenance. Wider terrace in a given slope demands for an increased riser height. Farmers tried to keep the riser height to a minimum, because increasing the riser height leads to higher risk of terrace failure. However, riser height unavoidably increased as slope increased $\left(R^{2}=0.78\right)$ (Figure 3).

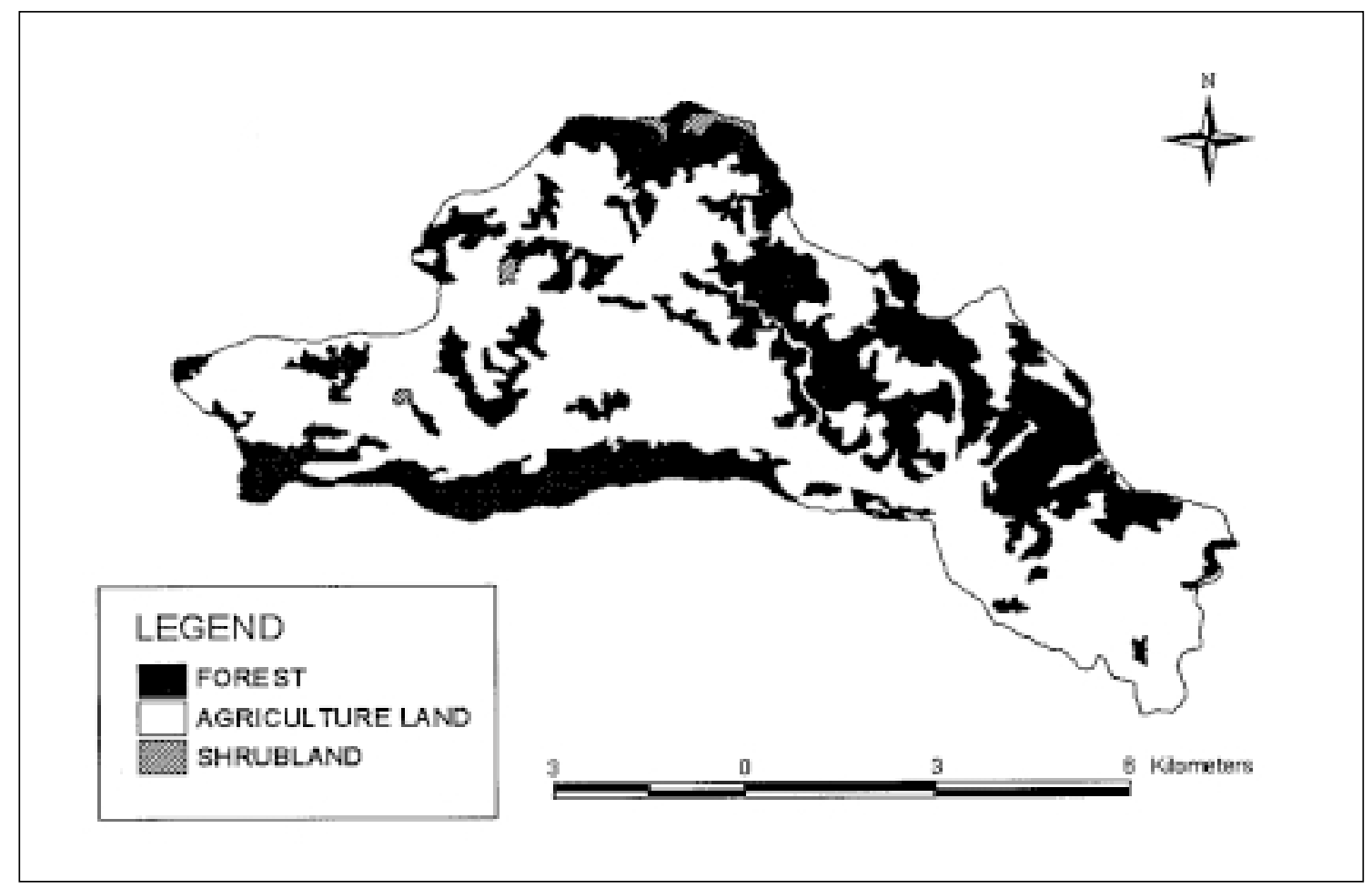

FIGURE 1. Land use distribution in Paundi Khola Watershed 


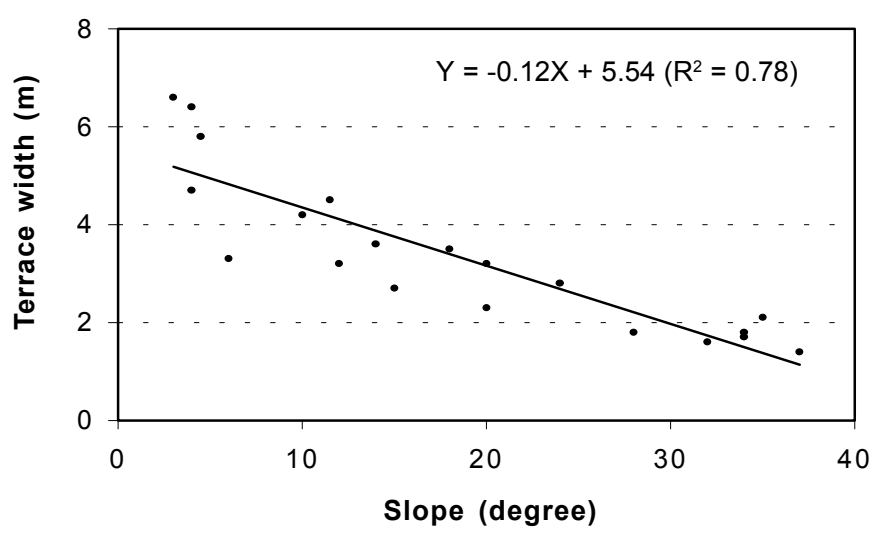

FIGURE 2. Relation between slope and terrace width

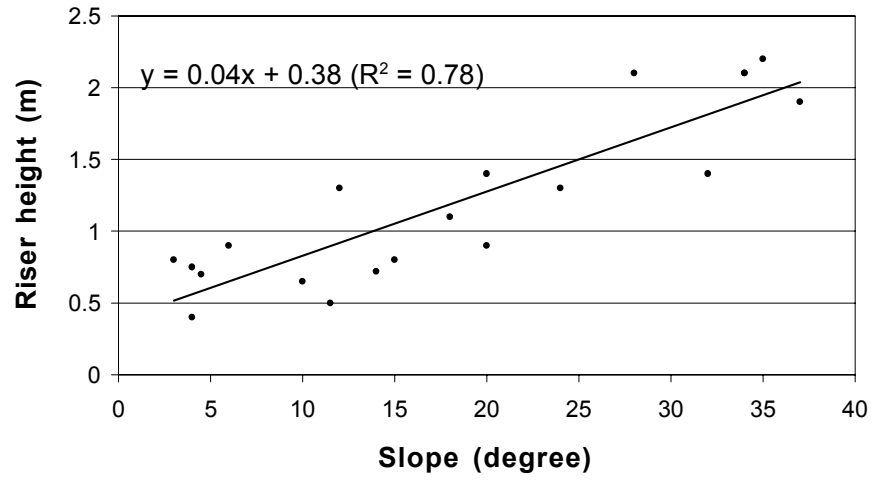

FIGURE 3. Relation between slope and riser height

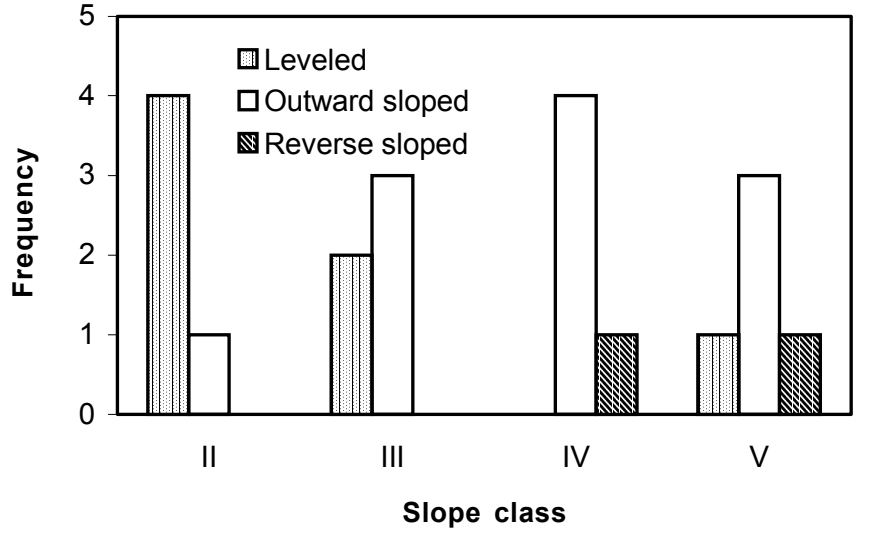

FIGURE 4. Terrace frequency in various slope classes

Types of terraces

In steeply sloping areas, farmers preferred to construct outwardsloped terraces. The construction of level or reverse sloped terraces in the higher slope classes requires more cutting and filling of earth. Outward-sloped terraces werethe mostcommon, comprising $55 \%$ of the total, followed by level terraces, with $35 \%$ of the total number of terraces. Reverse-slope terraces were least frequently-observed, with only $10 \%$ of the total; they occurred only on the higher class slopes (Figure 4). Generally, outwardsloped terraces were common in the middle slope class while level terracesoccurred primarilyon lower classslopes. Theresults arein conformity with thestatement put forward by Carver (1995) that farmersmodify terrace characteristicsto accommodatelocal slopeand climatedemands.
Types of riser surfaces

Most of thefarmers were unaware of theimportance of vegetation on the riser surface as a binding element. The natural vegetation in theriser surfacewasscraped every year beforecrop cultivation (mostly paddy cultivation). However, thescrap vegetation provides green manure for the field. Farmers believed that removing the vegetation helped control insects and other pests. The farmers' logic is in line with results reported by Tamang (1992) in a study focusing on the hills of Nepal.

According to Carson (1992), terrace risersin Nepal arecommonly stone-lined, vegetated, or purposely cut to bare soil. Riser surfaces observed in the study area included natural grass or improved varieties such as Napier, stone lining and bare surface. The most common were natural vegetation ( $40 \%$ of the total observed), followed by bare surface (30\% of the total). $20 \%$ are stone-lined while only $10 \%$ of the total was vegetated with improved varieties of grasses.

\section{Bund plantation}

Out of all observations, only $45 \%$ of the terraces had bund plantation of grasses, fruits and fodder species. The practice of bund plantation varied according to the type of land. A low proportion of planted bunds was observed on irrigated land (paddy field) in comparison to rainfed land. Only $16.67 \%$ of irrigated land had bund plantation while $57.14 \%$ of rainfed land was found to have bund plantation.

Among species most commonly planted on bunds were fodder trees such as Artocarpus lakoocha (badahar), Ficus roxburghii (nimaro), Ficus semicordata (khanyu), and Melia azaderach (bakaino). Also planted werefruittreessuch as banana and orange, annual crops such as soybean and black gram, and natural grasses such as Eulalopsis binata (babio) and Imperata cylindrical (siru). Fodder trees were not planted on the bunds of paddy fields because of their shading effect, which might hinder crop growth.

\section{Cropping pattern}

Paddy, millet, maize and wheat were the major cereal crops cultivated in the PKW. The irrigated land was predominantly devoted to paddy, while either maize or wheat came afterwards to completetherotation. On rainfed land, millet was themain crop, planted in rotation with maize and vegetables. Paddy was the preferred crop wherever irrigation was available. Even on rainfed lands, farmerswereableto raisespecial varieties of upland paddy (ghaiya); thanks to its tolerance of moisture stress. The cropping patterns observed on irrigated lands were paddy and paddy/maize/ millet, and upland paddy and millet/maizeor millet and maize/ vegetables or paddy/millet/maize on rainfed lands.

Irrigation practices

Irrigation systems wereemployed in thelower alluvial plainswhere paddy cultivation was practised. Farmers flooded the lowland fields excessively because they believe that more water results in higher yield. Lack of proper drainage had led to landslides and slumping where the underlying bedrock was not stable. No irrigation system existed in the mid- and higher elevations where cultivation was limited, for the most part, to millet.

\section{Construction material}

Clay and stone were the materials most commonly used in construction of terrace risers and benches. Homogenous clay was commonly used for riser construction. Stones along with clay were also used in some areas, especially in landslide-affected areas. The stones used for construction were not of uniform size and grade. 
Indigenous technique for judging slope stability

People usually judged slopestability by the presence or absence of paharo (local term used for exposed massive base rock) at the toe of thehill slope. Aslopewas considered stableif such paharo is present; lack of paharo was taken to indicate instability. This criterion was taken into account when houses were constructed or settlements established. However, terraces were constructed wherever irrigation was available for paddy cultivation irrespective of slopestability.

\section{Terrace maintenance}

Farmers maintained the terrace against failure by using mud, grass, and sometimes stonesto repair cracks in the paddy field. If the cracks were likely to develop further in subsequent events of massmovement, they tended to fragment theterrace. They practised cutting of earth from the elevated portions or the field and used it to fill in depressed areas. However, they continued to exploit such lands until the slope/ terrace completely failed or became otherwise uncultivable.

\section{Conclusions}

There existed a high degree of negative correlation between the terrace width and slope $\left(R^{2}=-0.78\right)$, as well as between riser height and slope $\left(R^{2}=0.78\right)$. From this, it can be concluded that the hill farmers are intentionally accommodating terrace dimensions to topography. However, the types of terraces constructed and maintained were not al ways adequately related to slopesteepness. Outward-sloped terraceswerefrequently used in the higher slope classes, which can lead to increased surface run-off and downslope sedimentation. Further study of the possibility of gradually transforming of outward-sloped terraces to level or reverse-slope terracing is recommended. Immediate solutions for increased run-off and sedimentation due to outward-sloped terraces in the higher slopeclasses might be the adoption of supplementary soil conservation measures such as contour drainage, conservation ponds, and contour planting.

Only $45 \%$ of the observed terraces featured bund plantation. Most were in the upland areas rather than irrigated low lands. Farmers are unwilling to practice bund plantation in the paddy field because the species planted could reduce primary crop yield through above- and below-ground competition. This sort of problem might have occurred due to the selection of inappropriate species for the purpose. Conservation agents should help farmers choose the appropriate species to achieve best results.

In the uplands, no irrigation facilities were observed and rain is therefore the only source of water. Irrigation practices existed in the lower alluvial plain where paddy fields predominate. However, the irrigation practices are not sound, and poor drainageisa significant problem. Farmers practised flood-irriga- tion using river water conducted to the terraces through small channels. The impounding of water without regard to slope stability may bea root cause of terrace failure and may also induce landslides.

Scraping of vegetation on the risers before every cropping season was commonly practised, supposedly to provide green manureand destroy insectsand pests. Although itmay have benefits, this activity certainly leads to soil loss. Planting of improved varieties of grasses on therisers will notonly bind thesoil but also provide a rich source of fodder for the livestock.

Acknowledgements

The authors are thankful to NARMSAP/DANIDA, Western Regional Office, Pokharafor financial support. The paper is based on research project paper submitted by the first author to Institute of Forestry, Pokhara, Nepal for the partial fulfilment of Bachelor of Sciencein February 2001.

\section{References}

Carson B. 1992. Theland, thefarmer and thefuture Kathmandu: International Centre for Integrated Mountain Development. Occasional paper no 21. $74 p$

Carver M. 1995. How do indigenousmanagement techniques affect soil and water movement?In: Schreier H, PBShah and SBrown (eds), Challengesin mountain resourcemanagement in Nepal: Processes, trends, and dynamicsin middle mountain watersheds. Proceedings of aWorkshop held in Kathmandu, Nepal; 1995 Apr 10-12. Kathmandu: International Centrefor Integrated Mountain Development / International Development Research Centre/ University of British Columbia. p 193-202

DSC. 1992. Soil conservation and watershed management activities(Definition, scopeand workingstrategy). Kathmandu: Department of Soil Conservation, HMGN. 56p

DSCO. 1998. Watershed management plan of Paundi Khola sub-watershed. Lamjung: District Soil Conservation Office, HMGN. 78p

Hafeez S (ed). 1998. Appropriate farming technology for cold and dry zones of Hindu Kush-Himalayas. Kathmandu: International Centrefor Integrated Mountain Development. $153 \mathrm{p}$

LRMP. 1986. Land systems, land utilization and agriculture forestry reports. Ottawa: Land ResourceMapping Project, Kenting Earth Sciences Ltd. 263p

Mahat TBS. 1987. Forestry-farming linkages in the mountains. Kathmandu: International Centre for Integrated Mountain Development. Occasional paper no $7.48 \mathrm{p}$

Pandey SP, DB Tamang and SN Baidya. 1995. Soil fertility management and agricultural production issues with referenceto themiddlemountain regions of Nepal. In: Schreier H, PB Shah and SBrown (eds), Challengesin mountain resourcemanagement in Nepal: Processes, trendsand dynamicsin middle mountain watersheds. Proceedings of aWorkshop held in Kathmandu; 1995 Apr10-12. Kathmandu: International Centre for Integrated Mountain Development / International Development Research Centre/ University of British Columbia. p 41-9

Pratap T and HR Watson. 1994. Sloping agricultural land technology (SALT). Kathmandu: International Centre for Integrated Mountain Development. Occasional paper no 23. $140 p$

TamangD. 1992. Indigenoussoil fertilitymanagement in thehills of Nepal: Lessons from an east-west transect. Kathmandu: Ministry of Agriculture, HMGN / Winrock International. Research report series no $19.59 \mathrm{p}$

Warren DM. 1991. Using indigenous knowledge in agricultural development. Washington DC:TheWorld Bank. World Bank discussion papers $127.46 \mathrm{p}$ 